\section{MESONERO, VIAJERO POR FRANCIA Y BÉLGICA (1840-1841)}

\author{
Concepción Núñez Rey \\ Departamento de Filología Española III \\ Facultad de Ciencias de la Información \\ Universidad Complutense de Madrid \\ cnunezre@ccinf.ucm.es
}

\begin{abstract}
Soon after his return, the weekly Semanario Pintoresco Español published an account of the trip Mesonero Romanos made across France and Belgium between the years of 1840 and 1841. He shared his experiences in a series of 16 articles that he wrote between the months of April and August of 1841, which he would republish in a single volume shortly afterwards. We can see in his writings the way Mesonero viewed the people and cultures he visited. His work provides numerous comparisons and reflections about Spain; which remained always present in his mind. Readers familiar with Mesonero's writings on Madrid customs and manners may be surprised by his fascination with technical progress and the more advanced aspects of the societies he visited.
\end{abstract}

ABSTRACT: Mesonero Romanos; Semanario Pintoresco Español; France; Belgium; travels; traveller; women; modernity; technical; progress.

A Pilar Palomo, que me invitó a este viaje con Mesonero

\section{EL VIAJE}

La literatura nacida de los viajes ha suscitado siempre especial interés, no solo por la información que nos ofrece acerca de los espacios recorridos, o por los anhelos y nostalgias que es capaz de provocar en nosotros, más allá, es capaz de estimular intensamente nuestra imaginación y nuestra reflexión acerca de mundos nuevos, desconocidos antes, en los que parece renovarse la vida entera.

Es una literatura que tiene como motivo la experiencia del viaje, pero que nace de un autor que tiende sobre los espacios recorridos su propia mirada, es decir, que filtra las realidades observadas a través de su pensar y su sentir. Se suma lo que podríamos Ilamar estimulación de la mirada, que se mantiene mucho más atenta o alerta ante

\section{MESONERO, ON HIS TRAVELS TROUGH FRANCE AND BELGIUM}

RESUMEN: El testimonio del viaje que Mesonero Romanos emprendió por Francia y Bélgica de 1840 a 1841, apareció publicado en el Semanario Pintoresco Español poco después de su regreso. Entre abril y agosto de ese año vertió su experiencia viajera en dieciséis artículos, que muy pronto reeditó reuniéndolos en un volumen. En estos textos descubrimos la mirada con que el autor contempla las sociedades visitadas, en la que está siempre presente España, dando lugar a constantes comparaciones y reflexiones. Para el lector habituado a sus artículos costumbristas madrileños sorprende su fascinación por el progreso técnico y el interés con que supo ver la modernidad de las sociedades visitadas.

PALABRAS CLAVE: Mesonero Romanos; Semanario Pintoresco Español; Francia; Bélgica; viajes; viajero; mujer; modernidad; progreso; técnica.

los espacios nuevos que ante los cotidianos. Fruto de ello, en un texto de viajes, un autor nos ofrecerá ampliamente su propia visión del mundo, incluso, con frecuencia, la desbordará.

Partiendo de esta idea, encierra un natural interés aproximarse a los textos de Mesonero Romanos, nacidos de su viaje por Francia y Bélgica entre 1840 y 1841. Un interés que se acrecienta al considerar que nuestro autor figura en la historia de la literatura asociado a una etiqueta muy precisa como observador de la vida madrileña, es decir, como un autor localista con la atención puesta en el fluir de la vida cotidiana de su ciudad: en síntesis, asociado al puro costumbrismo madrileñista.

En realidad, más que interés genera gran curiosidad descubrir en qué medida se transforma una mirada habituada al espacio delimitado de Madrid para abrirse a otros europeos, enteramente nuevos, como lo era Francia, centro histórico de todos los acontecimientos de aquel tiempo, y como era Bélgica, un estado naciente. 
Grandes sorpresas van a responder a nuestra curiosidad, principalmente, la amplísima y compleja visión con que Mesonero sabe acoger los mundos visitados, rompiendo, en consecuencia, la imagen tópica creada en torno a su figura. Ya desde el comienzo, en las primeras palabras introductorias de sus Recuerdos..., reflexiona con plena conciencia sobre los motivos que impulsan al viaje:

Entre las diversas necesidades o manías que aquejan a los hombres del siglo actual, y que ocupan un lugar preferente en su espíritu, es sin duda alguna la más digna de atención, este deseo de agitación y perpetuo movimiento, este mal estar indefinible, que sin cesar nos impele y bambolea material y moralmente, sin permitirnos un instante de reposo; siempre con la vista fija en un punto distante del que ocupamos; siempre el pie en el estribo, el catalejo en la mano, deseando llegar al sitio a donde nos dirigimos; ansiando, una vez llegados, volver al que abandonamos, y con la pena de no poder examinar los que a la derecha e izquierda alcanzamos a ver'.

Como en una amplia declaración de principios, más que de propósitos, y alejándose de toda visión trivializadora del viaje, Mesonero alude a un impulso del individuo que es búsqueda o anhelo de conocimiento, que es incluso anhelo insatisfecho de ubicuidad. Pero hay algo más: alude al mismo tiempo a una desazón, a un malestar característico del hombre de su tiempo que le empuja a una búsqueda permanente; un rasgo que hoy juzgamos definidor del temperamento romántico, y en el que participa conscientemente Mesonero, según vemos, a pesar de su declarada posición antirromántica.

\section{Un PRIMER VIAJE de Mesonero (1833-1834), EN TEXTOS DISPERSOS}

Mesonero había visitado Francia e Inglaterra entre 1833 y 1834. Un viaje de enorme trascendencia porque en él encontró los modelos que dieron origen al proyecto de fundar una revista. En palabras del autor: "me resolví a fundar una publicación mía propia, exclusivamente literaria, popular y pintoresca, nueva absolutamente entre nosotros en su esencia y en su forma, y a semejanza de las que con los títulos Penny Magazine y Magasin Pittoresque había visto nacer en Londres y en París; y el 3 de Abril de 1836 fundé El Semanario Pintoresco Español2".
La revista de cultura cuyo nacimiento conmemoramos aquí, y para cuya elaboración el autor adquirió durante el viaje la maquinaria moderna que iba a ser clave para su éxito. Gracias a la técnica empleada en la impresión y en la producción de imágenes, pudo abaratar los precios, e hizo accesible su lectura a sectores sociales más amplios: "Bajo todos estos conceptos creo haber hecho un verdadero servicio a las letras y a las artes con la importación en nuestro país de esta clase de publicaciones pintorescas, o ilustradas, como ahora se dice, venciendo los formidables obstáculos que a ello se oponian por la falta absoluta de artistas conocedores del grabado tipográfico, y hasta de papel y de máquinas propias para la impresión ${ }^{3 "}$.

Pero de ese viaje, tan trascendente en lo práctico, en el que Mesonero se presentaba como periodista, no nos dejó un detenido testimonio literario. Tan solo textos dispersos $^{4}$, entre ellos, unos artículos esporádicos publicados en Diario de Avisos de Madrid, como el titulado "La vuelta de París" (16 y 17-IX-1835), dentro de la serie "Panorama matritense". Lo reeditó en 1862 y en 1881 como epílogo en la edición de sus artículos viajeros, donde Mesonero justifica el añadido del remoto texto: "porque, tratando del mismo asunto y en igual estilo, resume el pensamiento crítico y la lección moral que se propuso el autor" ${ }^{5}$. Asimismo, incluyó en estas ediciones, como capítulo XII, un artículo más remoto aún, "Entierro de Víctor Ducange", también fruto del primer viaje $y$, según el autor: "en la ocasión en que estaban en el apogeo de su celebridad las nuevas doctrinas literarias, apellidadas romanticismo, cuya exageración tanto se prestaba al ridículo"6. Lo había publicado en La Revista Española, a poco de su regreso en $1834^{7}$, y encierra especial significado porque, como vemos, se trata de un testimonio del antirromanticismo del autor, que se corresponde con el muy citado artículo "El romanticismo y los románticos" (1837), pero que se anticipa a este en más de tres años, en un momento en que, como sabemos, el movimiento iniciaba su triunfo en España.

Más tarde, en épocas distantes, fueron apareciendo otros artículos referidos al viaje en el Semanario Pintoresco Español. El primero lo dedicó a "Nuestra Señora de París" (18-IX-1836), con una detenida descripción de la catedral, envuelta en sus avatares históricos. Mucho después apareció el artículo titulado "El primer día en París" (28-V-1837), 
en que resume el autor la precipitación del viajero que recorre sus espacios buscando anheloso cuanto la ciudad pueda ofrecer. El tono es desenfadado, casi irónico, pero revela ya aspectos que más tarde, en los textos de 1841, darán lugar a serena meditación ${ }^{8}$. Y, muy tardiamente, aún apareció en el Semanario "Una visita a la abadía de Westminster" (25-12-1840), donde a la descripción espacial sucede la emoción cuando se acerca al "rincón de los poetas": "Entonces no seréis español, ni francés ni inglés; os arrodillaréis a pesar vuestro ante la sombra del gran Shakespeare". Y le siguen en su admiración Milton, Bacon, Spencer, Adisson, Newton, Watt... y otros nombres ilustres.

En cuanto a noticias de aquel viaje, del que nunca llegó a componer Mesonero un testimonio completo, podemos trazar el itinerario seguido gracias a un solo texto, "Fragmentos de un diario de viaje" (ver nota 4), un material muy poco desarrollado que el autor conservó pero que no vio la luz hasta medio siglo después, tras su muerte. Sabemos así con cierto detalle que salió de Madrid a primeros de agosto de 1833 y pasó por Valencia y Barcelona antes de entrar en Francia por Portus; después, en forma más esquemática y con levísimas anécdotas, siguió por Perpiñán, Montpellier (donde visitó la tumba de Meléndez Valdés), Marsella, Aviñón, Lyon... hasta París, donde se detuvo largo tiempo. Meses después, pasó a Inglaterra por Calais y se instaló en Londres; de allí partió para Birmingham, Manchester y Liverpool, y regresó a Londres en Nochebuena. Celebró el año nuevo en París y regresó a finales de enero de 1834 por Tours, Burdeos, Toulouse, de nuevo Perpiñán y, ya en ruta hacia Madrid, por Barcelona y Zaragoza.

Por razones diversas, Mesonero aplazó su proyecto de describir las vivencias de este primer viaje, de modo que, llegada la ocasión de emprender el segundo en 1840, ambas experiencias se fundieron en lo referente a Francia, que fue en las dos ocasiones el país visitado con mayor detenimiento y propósito de estudio.

No obstante, sabemos por el propio autor que trazó una "memoria escrita" de aquel viaje y que ese texto sirvió de base para otro muy distinto, pero de singular importancia dentro de su obra porque nos permite conocer el ideario y la actitud comprometida del joven Mesonero. Lo publicó bajo el título "Rápida ojeada sobre el estado de la capital y los medios para mejorarla", incluyéndolo en el "Apéndice al Manual de Madrid (Descripción de la corte y de la villa)" en su edición de $1835^{\circ}$. En efecto, como en ningún otro lugar, Mesonero se sitúa en la posición de un ensayista ilustrado que describe con lenguaje muy sobrio, desnudo de toda retórica, los males que aquejan al funcionamiento social de Madrid, imagen del país entero. No se trata de un lamento espontáneo, muy al contrario, el autor utiliza datos que son fruto del estudio y la observación, ordenados o estructurados con todo rigor:

discurriendo primeramente sobre las causas físicas que la naturaleza puede oponer en nuestro pueblo a la perfección deseada, y tratando de investigar los medios con que el arte puede vencerlas o modificarlas, pasaré después a las causas políticas y morales o derivadas de las leyes y las costumbres. Las primeras intento reducirlas a la salubridad, comodidad y ornato de la capital; las segundas a la seguridad, vigilancia y beneficencia, y las últimas al estímulo del trabajo, la instrucción y el recreo de sus habitantes ${ }^{10}$.

En semejante tarea, en la que Mesonero se distancia de tal forma de sus artículos costumbristas que nos parece más bien ser continuador de la obra de los ilustrados, utiliza siempre como alternativa los modelos europeos, los que acababa de conocer y estudiar en su reciente estancia en Francia e Inglaterra; es la razón por la que esta obra ayuda a compensar el vacio de testimonios sobre el viaje. Se trata de breves alusiones, pero de enorme significado; como ejemplo, uno de los primeros problemas que aborda es el de la conducción de aguas a la ciudad, condición para cualquier iniciativa de desarrollo y obra de enorme coste ("por qué arredrarse [...] cuando se emplea en objetos de absoluta necesidad"); recuerda entonces el sacrificio hecho para "el canal de L'Ourq, emprendido por Napoleón en beneficio de la población de París" (p.38).

Todo este magnífico documento, que retrata por dentro la vida de Madrid en aquel tiempo, merece un estudio atento, pero excede nuestra tarea central. El espíritu de admiración por todo signo de progreso que anima estas referencias citadas se va a desplegar con toda amplitud en el testimonio literario que, esta vez sí, nos dio Mesonero de su segundo viaje a Europa. 


\section{EL VIAJE DE 1840 a 1841.}

\section{LOS TEXTOS Y LAS INTERPOLACIONES}

Tiempo después, ya consolidado el gran éxito del Semanario ${ }^{11}$, emprendió en agosto de 1840 un nuevo viaje europeo, esta vez por Francia y Bélgica, del que recogió más tarde la gran experiencia vivida en sucesivos artículos publicados en la revista. Con cierto humor, explicaba su impulso como un efecto contagioso de la agitación de los madrileños por el ansia de viajar, lo que se justifica por el encierro sufrido durante los recientes años de guerra ${ }^{12}$ : "no era de extrañar esta unánime resolución de viajar que impulsaba a los habitantes de Madrid [...] era el primer verano en que después de seis años de guerra y de casi completa incomunicación podian con libertad saborear el derecho a menearse" $\left(2-V_{1}, 140\right)$.

Sin duda, vivencias del primer viaje por Francia (1933) se fundieron en estos textos, pero D. Ramón adoptó en ellos la mirada inadvertida del que descubre por primera vez. No obstante, episódicamente, recuerda alguna circunstancia de aquel viaje en contraste con sus experiencias nuevas.

Aunque el autor no precisa la fecha de su regreso, algunos datos revelan que lo hizo en los primeros meses de 1841; entre ellos, por su renuncia a esperar la llegada de la primavera para seguir hacia Italia o hacia Inglaterra. Otros indicios indican también que pudo regresar a comienzos de 1841, porque en noviembre estaba en Bélgica y ya había regresado a Paris el 15 de diciembre, día en que fue testigo del traslado de los restos de Napoleón a los Inválidos.

Por otra parte, comenzó a publicar los "Recuerdos de viaje" el 25 de abril de 1841, siguiendo un plan muy estructurado para cuya elaboración, sin duda, hubo de emplear un cierto tiempo después de su regreso. Distribuyó el caudal de contenidos en dieciséis capitulos que se cierran con uno final el 22 de agosto siguiente, aunque aún añadirá otro, ya desgajado, el 26 de septiembre ${ }^{13}$.

En el mismo año 1841, Mesonero volvió a publicar los dieciséis artículos en un volumen ${ }^{14}$, según sus palabras, a petición de muchos de los lectores del Semanario Pintoresco. Introdujo sobre todo un cambio; el artículo suelto dedicado al sepulcro de Moratín lo incluyó, recortado, en el capítulo IX, donde describe el cementerio del Père Lachaise.
A lo largo de los años, aún volvió a publicar Mesonero estos Recuerdos de viajes en dos nuevas ediciones muy distantes. En la primera de ellas, veintiún años después ${ }^{15}$, los textos viajeros sufren alguna variación. El primer capítulo, que en el Semanario y en el volumen de 1841 se titulaba "Introducción", pasa a ser con el mismo contenido "Los viajeros franceses en España". Más adelante, inserta como capítulo VIII el artículo publicado en el Semanario en mayo de 1837, "Un día en París", correspondiente a su primer viaje a Francia y que supone una alteración de visión y de estilo; para justificar en cierto modo su inclusión lo subtituló "Episodio". Después, mantiene el capitulo IX de 1841 (ahora XI en 1862), con la inclusión del capítulo dedicado al sepulcro de Moratín. Y añade también un nuevo título en el capitulo XII: "Entierro de Víctor Ducange (Episodio) ${ }^{16 "}$.

El artículo XI, último dedicado a París que apareció en el Semanario, sufre la mayor modificación en la edición de 1862. Lo divide en dos bajo los títulos "El extranjero en París" (cap. XIV), y "Un año en París. Las exequias del emperador" (cap. XV). En el XIV se interrumpe el discurso para introducir una dura sátira titulada "Una beldad parisiense" $^{17}$. La segunda parte de aquel artículo XI original, que da lugar al capitulo $\mathrm{XV}$, sufre una variación de mucho mayor interés: aparece ahora, dos décadas después, la descripción del solemne acto del traslado de las cenizas de Napoleón, que Mesonero se excusó de describir en 1841. Lo recrea con todo lujo de detalles, lo que hace pensar que se mantuvo inédito pero fue escrito, como los otros textos, a su regreso del viaje. Al frente de esta edición se añadió todavía una "Advertencia del editor", firmada por F. de P. Mellado, en que vierte juicios muy certeros sobre el valor de estos artículos de viajes.

Otras dos décadas después, en 1881, ya al final de su vida literaria, Mesonero volvió a incluir sus Recuerdos de viaje $^{18}$ en una reedición de sus obras. Esta vez se limitó a repetir el contenido reordenado en 1862, según quedó expuesto, aunque reformó algunas notas y modificó levemente la "Advertencia del editor", que ahora apareció sin firma. Reconoce nuestro autor los cambios producidos en tanto tiempo por "la asombrosa marcha de los modernos adelantamientos, que han cambiado casi por completo las condiciones de la actual sociedad". Pero defiende el valor documental que los artículos conservan: "siguiendo su estilo propio y su manera analítica peculiar, acertó a trazar [...] un cuadro animado y crítico de la manera de 
existir de aquella sociedad, una brillante exposición de las impresiones producidas por su estudio en el ánimo de un español ${ }^{19 "}$.

Aunque sirvan como información adicional los artículos interpolados posteriormente, nuestra atención se centrará para el estudio en aquellos publicados en 1841, tanto en el Semanario Pintoresco, como en el volumen en que fueron recopilados con mínimas variaciones.

Los dieciséis artículos del conjunto inicial componen una estructura casi simétrica. Abarcan el viaje desde la pormenorizada salida de Madrid, avanzando lentamente por las sucesivas etapas en distintas poblaciones de España y Francia, lo que ocupa los cinco primeros capítulos, hasta la llegada a París. El descubrimiento de la gran ciudad detiene el viajar y ocupa una segunda parte de seis capítulos (VI-XI). Los cinco restantes (XII-XVI) contienen el recorrido por Bélgica dedicando la mayor atención a Bruselas y Amberes.

Capítulos I-V: de Madrid a París.

Capítulos VI-XI: París.

Capítulos XII-XVI: Bélgica.

Morosamente se va a desplegar el viaje desde la salida de la casa de postas de Madrid, hasta la repentina decisión de regreso desde París, resuelta en una frase.

\section{EL VIAJE COMO REPORTAJE}

En el largo recorrido descrito, Mesonero parte de Madrid a primeros de agosto de 1840, pero antes describe la agitación que recorre la ciudad por el deseo generalizado de viajar a diferentes lugares; en realidad, a cualquier parte. Compone así un dinámico cuadro en que el lector descubre lugares de la ciudad reveladores de usos y costumbres. Todo ello teñido de un tono irónico que ridiculiza el espectáculo de avidez generalizada.

Morosamente se despliega el viaje desde la Casa de Correos de Madrid, en una de cuyas diligencias viajará hasta Bayona. Al principio, se desinteresa por los lugares más cercanos de la ruta (Fuencarral, Alcobendas, San Agustín, Buitrago), o solo les dedica una leve alusión por alguna incidencia (Aranda, Burgos, Vitoria). El País Vasco atrae por primera vez su mirada desbordada en elogios: "el más delicioso panorama que una imaginación poética pudiera imaginar"20. Bayona ocupa todo un artículo de los Recuerdos... (II) en que Mesonero atiende los más diversos aspectos, geográficos, históricos, urbanísticos, administrativos o sociales, creando un modelo de presentación que ha de repetir básicamente en las restantes ciudades visitadas, y marcando ya los grandes rasgos que van a ir definiendo la imagen de Francia. El monótono recorrido hasta Burdeos atravesando las Landas, "su severo aspecto", convierten el capítulo (III) en una larga digresión sobre las comunicaciones en el país.

La llegada a Burdeos constituye un momento apoteósico; la ciudad se convierte para Mesonero en el modelo superior (incluso por encima de París), admirado "de tanta grandeza, de tan asombroso lujo, de gusto tan exquisito" (IV); y admirando al bordelés "para quien disfrutar de la vida es un negocio positivo, una necesidad real" (23-V, p. 165). Dedica especial atención a la deliciosa vida organizada en sus chateaux durante las vacaciones de verano, lo que genera una larga digresión sobre la lamentable manera de veranear en España y las dificultades diversas que ofrece la vida en el campo. Durante el trayecto entre Burdeos y París (V), solo elogia en Angulema las fábricas de papel por su reconocida calidad y buen precio (idea hasta tiempos recientes). Desatiende Poitiers, que encuentra decaída y registra la multitud de vendedores que asedian a los viajeros en Châtellerault, ciudad famosa por su cuchillería (como Albacete en España). Se detiene en Tours, ciudad que le atrae por su animado y elegante ambiente turístico y donde reconstruye una escena en el comedor del hotel (table d'hôte), que en lugar de limitarse a reproducir los usos cotidianos se convierte en una divertida sátira de los comensales. Ya camino de París pasa por Blois y Orleáns y presiente la cercanía de la gran ciudad por la dimensión y el dinamismo crecientes según avanza el carruaje.

A la gigantesca capital dedicará, como hemos señalado, seis artículos, en los que se propone abarcarla de forma ordenada. En el primero presenta la ciudad físicamente; su constitución y ordenación con innumerables datos precisos en cuanto a dimensiones o distancias. Nos introduce en las casas por los portales, las escaleras, entrando en las viviendas para mostrar su distribución ordenada en favor del confort, fruto del esfuerzo racionalizador al servicio 
del individuo, del conocimiento técnico y de la conciencia artística. De igual modo, registra el orden y cuidado de las calles que favorecen el tránsito por la ciudad: las aceras, el empedrado, los desagües, la iluminación, la numeración, las prohibiciones diversas, el control policial. Un exhaustivo documento de la infraestructura urbana.

Todo un artículo (VII) se ocupa del movimiento de la ciudad, de los medios de comunicación y transporte, del correo interno, de las clases de vehículos de alquiler, del transporte público (faetones, ómnibus, bearnesas) con su red de líneas y sus conexiones, incluso sus precios. Le seguimos por galerías comerciales (pasagges); callejeamos con él (como los "flaneurs") viendo los atractivos escaparates de mercancías que nos reclaman, que excitan el deseo de comprar (el germen de la sociedad de consumo). Aún aconseja al hipotético viajero resistirse al incesante estímulo publicitario. Del París cultural (VIII) se ocupa a continuación, repasando la inmensa oferta de conocimiento en todos los campos del saber: Arte, Ciencia, Letras, espectáculos; informando de la facilidad de acceso, del capacitado personal que los atiende. Acude a los templos antiguos (Nuestra Señora) y modernos (La Magdalena, el Panteón, los Inválidos). Renunciando siempre a las descripciones convencionales, visita también los famosos palacios, en especial, el Palacio Real de Orleáns, convertido en centro cultural de París desde 1778, con sus tiendas, cafés, teatros y museos. Todo el París monumental desfila ante su mirada.

Se encamina después (IX) hacia el Barrio Latino ("Cuartel latino"), con la Sorbona como centro, que en la historia ha irradiado las "revoluciones mentales de la moderna Europa". Se encuentra con sus estudiantes, temerarios; subversivos, que exhiben las melenas y las barbas de la rebeldía. Repasa los centros de instrucción, del Conservatorio a la Biblioteca o al Jardín de Plantas; y los Ateneos, reunidos en el "Instituto Real de Francia", donde se presencia en sesiones abiertas la intervención de grandes figuras. Una inabarcable actividad cultural y académica. Aún continúa su exploración por hospicios, asilos, hospitales, sociedades filantrópicas, cajas de ahorro, prisiones, mataderos, acueductos, canales, mercados, cementerios, admirando siempre su funcionamiento y su buena administración. Completando con este método ordenado el estudio de la vida parisina se ocupa de la casi infinita oferta de espectáculos (X): desde las óperas en la Academia Real de Música, o en el Odeón, a las representaciones de los grandes autores clásicos en el Teatro francés, sin olvidar la crítica a la "escuela apellidada romántica"; hasta llegar a los "teatros de Boulevard", al "Vaudeville", el Circo, e incluso a los espectáculos callejeros y a los conciertos y bailes públicos. Un recorrido exhaustivo. Finaliza su exploración de París (XI) repasando la extensa oferta de servicios en hoteles y restaurantes, recorriendo sus paseos y cafés y repasando las celebraciones y costumbres de la ciudad a lo largo de las distintas estaciones. Al final, cambiando el punto de vista y abandonando la mirada entusiasta, se lamenta de la soledad y la carencia de verdaderos afectos que sufre el viajero en medio de tan brillante sociedad.

Si en la mirada sobre Francia, las referencias comparativas vienen de España, para contemplar Bélgica la referencia frecuente será Francia, evaluando el grado de desarrollo en los dos países; pero esta vez no se abre un abismo de diferencias. Comienza su recorrido en Bruselas (XII) pero anticipa al lector una información detallada sobre el país, desde su historia a su sistema económico y a su desarrollo. De la capital nos ofrece, como hizo en las ciudades francesas, una exhaustiva exploración de su urbanismo, sus monumentos, sus espectáculos, sus sistemas de educación y protección social ("todo arreglado al nivel civilizador de la sociedad moderna"). Con parecido detenimiento contempló Amberes (XVI y último), y más de pasada, atendiendo a los aspectos más destacados, las otras ciudades importantes que visitó: las flamencas, Gante y Brujas (XIV), y las "walonas" [sic], Malinas, Lieja y Namur (XV). En su recorrido por todas ellas son frecuentes las evocaciones históricas referidas a la dominación española. Por encima de todo, de la mirada de Mesonero sobre Bélgica destaca y adquiere especial significado el documento que nos ofrece sobre su sistema de "caminos de hierro" (XIII), al que hemos de volver.

\section{LA ADOPCIÓN DE UNA MIRADA}

En la literatura viajera parece esencial descubrir la calidad de la mirada que el autor tiende sobre la realidad, su forma de mirar. Inevitablemente esa mirada es compleja porque el autor mira siempre incorporando su capacidad de percibir, su emotividad, sus conocimientos, sus recuerdos, su ideología, todo cuanto conforma su personalidad. $Y$ todo ello aflora aunque el autor haya deseado someter su mirada a estricto control. 
Es el caso de Mesonero, quien parece muy consciente de la necesidad de elegir un punto de vista, una manera de enfocar y transmitir la experiencia del viaje. Se multiplican así (sobre todo en los primeros artículos) las declaraciones al lector sobre su proyecto y sus intenciones. Al principio los va definiendo por negación, hasta el punto de iniciar todo el ciclo de artículos con uno introductorio en que satirizaba duramente un prototipo de escritor francés (el transpirenaico), cuyos textos sobre España añadían a su exagerada extensión, un cúmulo de ideas tópicas, falsas, plagiadas incluso, en las que incluía ampulosamente buenas dosis de aventuras imaginarias.

Compone así todo un alegato contra un antimodelo, frente al que opone nuestro autor su propósito modesto de ofrecer, con "procedimiento velocífero [...], las mínimas dosis de unos artículos razonables con que entretener a mis lectores honradamente, y hacerles recordar, si no lo han por enojo, mi parlante curiosidad ${ }^{21 "}$.

Conectando con esta propuesta defiende su afán de objetividad, rehuyendo "juzgar a mi modo y de una sola plumada del carácter, costumbres, historias, leyes y aspecto físico del país" (9- $V, 142)$. Añade Mesonero nuevos matices para delimitar los márgenes de la labor que emprende: "no busque el lector en estos artículos ni metódica descripción; ni pintura artística o literaria; ni historia propia, más o menos realzada con picantes anécdotas; ni sátira amarga siempre, ni pretexto constante para hacer reír a costa de la razón. -Pues entonces ¿a qué se reduce su contenido? -A poca cosa. A algunas observaciones propias, a tal cual comparación imparcial a tal otra crítica templada, a indicaciones tal vez útiles" $(9-\mathrm{V}, 149)$.

Afirma también un criterio selectivo para verter el gran caudal de información recogido: él no es "de los que copiando las hojas de su libro itinerario adoptan o trasladan cándidamente su contenido" (30-V, 173).

Más avanzada la publicación de los artículos continúa reflexionando sobre su propia labor, ahora ya más en positivo; su intención es: "dar razón de las sensaciones que me produjo la vida animada de los pueblos, más bien que el hacer un inventario de sus riquezas" (23-V, 167). La "vida animada", recordemos esto. Reforzando esta idea, afirma más tarde su propósito modesto de "recrear la memoria propia, y excitar algún tanto la curiosidad ajena
[...] arriesgar solo aquí nuestras propias impresiones [...] sin que sea lícito pedirme cuenta más que de lo que decimos, y no de modo alguno de lo muchísimo que dejaremos por decir" (6-VI, 181). Sale así al paso de los juicios que puedan generar sus textos, anticipando, según afirmaba, "el verdadero punto de vista bajo el cual desearía fuesen juzgados estos pobres borrones" (9-V, 149).

Sobre este afán de selección propone el autor un método, que recomienda a sus lectores y posibles viajeros, y que es aplicable al modo como aborda el relato de su viaje: "reducido en lo posible a una observación meramente pasiva aguarde a que el tiempo venga a colocarle en el verdadero punto de vista desde el cual ha de examinarle" (6-VI, 182)

La mirada de Mesonero que nos va a guiar por los espacios del recorrido es, pues, muy selectiva, marcada por la objetividad, decantada, remansada, atenta a las impresiones y vivencias provocadas por la vitalidad de la sociedad, y muy consciente de que el punto de vista determina toda visión de la realidad.

Es tal su afán de objetividad que Mesonero busca el modo de eliminar su propio "yo" como protagonista del viaje y como narrador, un "yo" que juzga "impertinente y vanidoso" (según él, presente en los "viajeros contemporáneos" suyos); pero al eliminar el yo, como es lógico, desaparecen las circunstancias personales del viaje, excepto en las ocasiones en que se dirige al lector para orientarle sobre su propósito o para aclarar algún aspecto: "yo salí de Madrid en los primeros días de agosto" (2-V, 140); "a mi modo de ver", "ni es de mi propósito, ni está a mis alcances" (6-VI, 184).

Para sustituir ese yo son varios los procedimientos. Unas veces se oculta en un "nosotros", que puede incluir a los compañeros de viaje: "nos contemplábamos unos a otros" (2-V, 141); "llegamos a las nueve de la noche" $(2-\mathrm{V}, 141)$. 0 que puede aludir a los españoles: "en nuestro Madrid" (6-VI, 184); "es entre nosotros una excepción honrosa" $(9-V, 150)$. 0 que puede aludir solo al propio autor en una aparente generalización: "Seríamos injustos" (16-V, 159); "Aconsejémosle..." (6-VI, 182); "Hemos mencionado ya..." (4-VII, 214).

Lo más frecuente no obstante es que el autor aluda a sí mismo en tercera persona, convertido en "el viajero", "el 
extranjero" o "el forastero": "La vida del extranjero en París" (13-VI, 192); "el viajero atemorizado involuntariamente" (1-VIII, 247). También alude a un viajero hipotético en el que se incluye: "no difícil de comprender por el forastero" (6-VI, 182); o al que desea advertir: "Ignoro si el viajero se dará por satisfecho" (6-VI, 182). Llega incluso a utilizarle para ocultar una emoción personal: "si el viajero es español, crece de todo punto su interés" (26-IX, 305).

Se trata, como vemos, de un método de distanciamiento muy meditado por parte del autor, que viene a reforzar no solo el afán de objetividad, sino también, en gran medida, la libertad para presentar su opinión como idea aceptada de modo general, difícil de cuestionar. $Y$ no solo en esto manifiesta Mesonero sus precauciones; son frecuentes los incisos y los giros repletos de justificaciones para atenuar sus afirmaciones: "Se ha dicho, no sin fundamento, que al establecer una nueva colonia lo primero que hacian los españoles era fundar un convento" (11-VII, 221); "Sin embargo, en obsequio a la verdad, no puede dejar de convenirse" $(9-\mathrm{V}, 150)$; "a fin de hacer resaltar las respectivas ventajas con la debida imparcialidad y buena fe" (16-V, 158). Se pueden multiplicar los ejemplos.

Con este último descubrimos en la mirada de Mesonero un nuevo tinte, que es de calidad moral; por una parte son afirmaciones sobre sí mismo que siempre implican en él una alta estima y exigencia en su comportamiento: "quien se precia de hombre honrado" (9-V, 149); "hablo aqui con la honradez propia de un hijo de Castilla" (2-V, 140); con igual autoestima, aunque distanciándose del "yo": "no puede menos de conmoverse profundamente el hombre sensible" (26-IX, 305).

Tantas cautelas y declaraciones de intenciones nos conducen al lector, al que Mesonero invoca con frecuencia estableciendo con él un diálogo muy cercano para orientarle en el desarrollo del texto y para justificar omisiones, digresiones o interrupciones: "Sin duda que nuestros lectores no esperan encontrar aquí una descripción artística de estos célebres monumentos" (27-VI, 207). En algún momento llega incluso a convertir al lector en un confidente de sus vivencias: "¿Qué es lo que le falta? (se dirá). ¡Qué! ¿No lo han adivinado mis lectores? Le falta la sociedad intima y privada, aquella que produce las verdaderas relaciones del corazón" (18-VII, 228-229). Pero el propósito expresado con mayor frecuencia por el autor es mantener siempre vivo el interés del lector, anticipándose a sus posibles reacciones: "acaso hayamos abusado de la paciencia del lector" (18-VII, 231); "Por no molestar demasiadamente la atención de nuestros lectores" (25-VII, 238); "ya debe [sic] hallarse fatigada la atención de mis lectores" (22-VIII, 270); "Reclamando sinceramente la indulgencia de mis lectores" (22-VIII, 271).

Cabe preguntarse por la causa de esta suma de cautelas y precauciones con que envuelve Mesonero el relato de su viaje, y cabe responder, leídos los textos, que el mundo europeo representado en ellos a menudo entraba en colisión con las realidades de la sociedad española y con su distinta visión del mundo. En apoyo de esta respuesta vamos a encontrar innumerables testimonios.

Parece evidente que en esta mirada elegida por Mesonero, cautelosa, objetiva, distanciada, celosa de su intimidad, queda muy poco espacio para la efusión sentimental de cualquier índole. En efecto, no son solo escasas, sino poco expansivas, vertidas con un léxico entibiado, tanto para expresar su amor a la patria: "no sin palpitar nuestros pechos al dejar momentáneamente nuestra amada España" (2-V, 142); como para realizar valoraciones: "huyendo justamente de todo movimiento de admiración exagerada" (6-V, 159); como para expresar la impresión que le causa la contemplación de una ciudad: "tal es la agradable sorpresa" (23-V, 165). También cuando su valoración contiene un alto significado moral: "el extranjero suspenso siente despertar un movimiento de simpatía por una nación que sabe respetar así la memoria de sus pasados" (26-IX, 305); e incluso renuncia a describir una emoción intensa: "no hay palabras para expresar su indefinible satisfacción" (1VIII, 247).

En este contexto de sobriedad expresiva, parece una deliberada parodia alguna frase retórica como la que cierra la descripción de los festejos para la inauguración de la estatua de Rubens: "embargaban el alma y ponian en suspenso los sentidos" (22-VIII, 271).

En cambio, y a pesar de todo ello, el lector siente fluir sin cesar un sentimiento melancólico, que se funde con la lucidez, detrás de la mirada de Mesonero, quien lleva siempre en ella como referencia el recuerdo de España frente a lo que sus ojos contemplan. 


\section{EsPAÑA, PRESENTE EN LA MIRADA}

Desde la misma frontera entre España y Francia comienza Mesonero a establecer comparaciones entre los dos paises: "se empieza a notar más aseo en el aspecto de las casas, bien construidas y blanqueadas, más gusto y oportunidad en la colocación de los pueblos y caseríos, más orden y policía en su administración interior [...] desgraciadamente habrá de reconocerse la sensible diferencia de una y otra administración" ( $9-\mathrm{V}, 150)$. Con este suave lamento no ha hecho más que comenzar la descripción de las profundas diferencias que separaban a ambos paises. También desde el principio aparece la guerra como causante de las deficiencias de la sociedad española, y no alude solo a la reciente guerra carlista, sino a "nuestras eternas discordias civiles que alternativamente obligan a una parte de la población a huir del patrio suelo" $(9-\mathrm{V}, 151)$.

Mesonero se propone enseñar, mostrar modelos dignos de ser imitados y lo hace exhaustivamente cuando los descubre, aplicando una lente de precisión, dando lugar muchas veces a extensas digresiones. Al mismo tiempo contrapone el modelo español, pero solo con alusiones más breves a las dolorosas realidades, y muchas veces mediante sobreentendidos. No obstante, según veremos, su propósito no es obviar los males de su patria ni hurgar en ellos, sino tratar de abrir esperanzas, de buscar soluciones: "en el momento en que nuestro hermoso suelo bien administrado, pacífico y seguro" $(9-V, 151)$.

Con la multiplicación de los ejemplos se va dibujando el panorama respectivo de Francia y España, ya avanzada la primera mitad del siglo XIX. Podremos verlo revisando algunos de ellos de sumo interés sobre diferentes temas, que, en su afán de objetividad y de objetivizar, Mesonero denomina siempre "objetos"22, casi siempre vinculados a la actividad viajera.

Uno de los primeros "objetos" son los "hotels"23, lo que en España se denominada "paradores o posadas", según el autor, quien describe con todo detalle la calidad del edificio y sus dependencias, de las habitaciones y su mobiliario, de los empleados y su servicio. Un sistema de hospedaje que el lector imagina muy próximo al actual, de asombrosa modernidad. Y lo que se ha descrito es un hotel de Bayona, que "en vano buscaría en nuestro país en pueblos tan importantes como Sevilla, Valencia, Burgos y Zaragoza".
El mismo Madrid, como afirma, solo ofrece "tres o cuatro malas fondas, o la prosaica vida de las casas particulares de huésped". Y propone "cubrir esta vergonzosa falta, disponiendo en alguno de los grandes edificios inmediatos a la Puerta del Sol un parador" (9-V, 152).

En contraposición, las posadas españolas "permanecen poco más o menos en el estado en que las pintó Cervantes hace casi tres siglos", lo que considera una de las causas que "retraen al viajero del intento de visitarnos" (9-V, 151). Vemos que Mesonero nos ahorra la descripción de esas posadas, pero la alusión es suficiente para hacer comprender al lector. Este será su método habitual.

Con aparente modestia, se propone dar unas "indicaciones sobre los medios de comunicación" en Francia, pero en realidad se extenderá a lo largo de un artículo para informar exhaustivamente de su funcionamiento, empezando por la red de carreteras, su buena construcción y conservación, los puentes colgantes, los diques y murallones en los ríos. Todo lo que permite un tránsito cómodo al viajero; el mismo que viene "de sufrir [claro está, en España] las bruscas ondulaciones de nuestro suelo, sus carreteras desniveladas, y sus desencajados pedruscos", atravesando arroyos o torrentes, o ríos en "una débil barca" $(16-\mathrm{V}, 158)$.

El autor dedica un espacio mayor a los carruajes, sobre todo a los servicios de las diligencias, más rápidas, frecuentes y extendidas por toda Francia. Las españolas son semejantes pero solo cubren unas pocas grandes líneas: "desde Madrid a Bayona, a Sevilla y Cádiz, a Zaragoza, Valencia y Barcelona". El resto del país se halla "en el mismo grado de incomunicación que en el pasado siglo" (16-V, 158).

Pero aún Ilega más allá Mesonero, comprendiendo en qué se funda la perfecta organización de las comunicaciones en Francia: "son testimonios constantes del entendido celo de un gobierno que en todas ocasiones ha dado la mayor importancia a la rapidez y a la comodidad de la circulación interior" (16-V, 158).

A la calidad de los servicios que Francia le ofrece se suma la belleza del paisaje en una imagen casi idílica, una de esas impresiones que nos anunció:

A tan grandes comodidades materiales se reúnen el grato aspecto de las campiñas, los crecidos arbolados que cons- 
tantemente cubren ambas orillas del camino, la inmensa multitud de casas de posta, hosterias y paradores que le interrumpen a cada paso, y la risueña perspectiva de mil y mil pueblecitos que la vista alcanza a descubrir en el fondo de los valles, sobre las altas colinas, a las márgenes de los ríos y a los lados del camino; el majestuoso curso del Garona, el Loira, el Saona, el Ródano y el Dordogne, poblados de barcos vapores y veleros; el interminable tránsito de caminantes en toda clase de carruajes y cabalgaduras, y la seguridad, en fin, absoluta contra todo asalto de malhechores, de día, de noche, en carruaje propio o en diligencia pública $(16-\mathrm{V}, 158)$.

Mesonero mantiene muy atenta su mirada a todo signo de progreso, sobre todo cuando viene a favorecer el desarrollo de la vida humana: el confort, la comodidad, las costumbres refinadas. Admira siempre en las ciudades de su recorrido la arquitectura, el trazado urbanístico, la buena administración, reflejada en la seguridad pública, en los numerosos edificios públicos dedicados al bienestar social, en lo físico y en lo cultural: tanto centros educativos, bibliotecas, museos o teatros, como hospitales, asilos, hospicios o cárceles, y todo ello incluso en ciudades pequeñas.

Burdeos se convierte para él desde su llegada en la joya representativa de Francia por su belleza y grandiosidad. Contempla la ciudad desde diversas perspectivas y recorre sus avenidas, los "boulevards", asiste a espectáculos y admira la vida del buen burgués bordelés, cuya casa es un templo de "magnificencia y lujo", de refinamiento y buen gusto, y "para quien el disfrutar de la vida es un negocio positivo, una necesidad real" (23-V, 165). Una vida de placer que en verano se traslada a sus "chateaux" en el campo, donde mantienen incluso una animada vida social.

Esta vez, la comparación con España da lugar a una extensa digresión para describir las lamentables circunstancias del veraneo en España, empezando por los "costosos palacios" de los "grandes de España y de los ricos capitalistas" y continuando hasta las clases más modestas que alquilan parte de una casa en un pueblo. Mesonero se recrea en pormenorizar los más diversos inconvenientes que aquejan a todos ellos, y resume las condiciones mínimas para poder disfrutar de la vida en el campo: "es preciso reunir ante todas cosas una absoluta seguridad y sosiego, rapidez y frecuencia de comunicación, franqueza e intimidad en las relaciones sociales, buenos modales, y regular discreción en los habitantes de la campiña. Por desgracia poco de esto existe entre nosotros" (23-V, 166).

Avanzando en su recorrido hacia París surgen en las sucesivas ciudades nuevos motivos de comparación con España. En Angulema, descrita con dos trazos, se fija en la fabricación de papel, de muy superior calidad y mejor precio, por lo que lamenta: "desgraciadamente es uno de los ramos en que nuestra España se presenta fuera del nivel de las demás naciones industriosas" (30-V, 173).

Con especial interés recordemos, para terminar, la larga digresión sobre la actividad turistica que provoca en Mesonero su visita a la ciudad de Tours. Después de ofrecernos la panorámica que la envuelve a orillas del Loira, penetra en sus calles iluminadas, sus paseos, sus "hermosos cafés", su teatro, todo ello concurrido por una sociedad elegante y animada que incluía "infinitos forasteros", en su mayoría ingleses. La ciudad les ofrecía "una morada tan favorable a la salud y tan propia para gozar de los placeres de la vida". Lo mismo que encontraban en ciudades como "Niza, Pisa, Florencia o Nápoles". En la imaginación de Mesonero, la placentera descripción se alterna con la dolorida meditación:

trasladábase mi imaginación a las encantadoras márgenes del Guadalquivir, y como que se lamentaba en silencio de que ya que el cielo bondadoso presta iguales y aun mayores dones a nuestro suelo, no sepamos aprovecharlos [...]. Si algún día la mejora de nuestros caminos, la multiplicación y facilidad de las comunicaciones, la seguridad personal, el establecimiento de buenas fondas y paradores, la tolerancia y los buenos modales en los paisanos, y el interés, en fin, bien entendido del pueblo en general, llegan a hacer accesible nuestra España a los viajeros touristas, especialmente a los ingleses, para quienes es insoportable la idea de privaciones, de inseguridad y de desaseo, iqué manantial tan inagotable de riquezas no abririan a nuestro país centenares, miles de aquellos ricos huéspedes (30- $V$, 174).

Desde nuestra perspectiva actual, la esperanza de desarroIlo turístico expresada por el autor, ya cumplida con creces e incluso desbordada en las últimas cuatro décadas, adquiere valor especial como un estímulo original, un punto de partida casi premonitorio ${ }^{24}$.

Como hemos podido ver, Mesonero mantiene una mirada lúcida para comprender el atraso de su patria en con- 
traste con el progreso de Francia, y mantiene también la honestidad de su mirada para no ocultar los hechos ni sus causas, que en repetidas ocasiones atribuye a la diferente administración y gobierno de los dos países. No obstante, su análisis no conduce a una exaltada denuncia, muy al contrario, con tono siempre mesurado, plantea necesidades, busca alternativas, propone consejos. Responde a la realidad con el sentido práctico y positivo de un burgués defensor del progreso material de la sociedad, pero lejos de los arrebatos románticos de sus colegas contemporáneos.

Encontramos aún de sumo interés examinar la mirada cambiante que durante su viaje Mesonero dedicó a la mujer; una vez más, con el trasfondo en su retina de la situación de la mujer española. La tendencia inicial es contemplarla cortésmente como objeto bello: "las lindas bayonesas, cuyas expresivas facciones, ojos vivos, talle delicado, son proverbiales en Francia" (9-V, 150). Más adelante, incluida en su descripción elogiosa de las costumbres belgas, nos ofrece una imagen de la mujer como objeto moral, aunque sin emitir juicio alguno: "Las mujeres apenas se presentan por las calles más que en carruaje o para ir a misa o a vísperas; tampoco se asoman a las ventanas, y sólo se permiten un inocente ardid colocando ingeniosamente a los lados de aquellas y por la parte de afuera un juego de espejos [...] Ilamados Ladrones" (25-VII, 240).

Pero esta mirada fluctuante descubre otras realidades que la obligan a comprometer un juicio; el autor no lo rehuye, aunque lo expresa con suma cautela. Uno de esos momentos lo vive en la playa de Biarritz, donde:

no hay sitio especial para los bañadores [bañistas], cada uno se zambulle donde le place, sin distinción de sexo ni edad. Yo no sé si esta costumbre podrá o no perjudicar a la moral; pero lo que es al artista no podrá menos de serle útil para estudiar los diversos partidos del desnudo, y aun el autor fantástico podrá creer tal vez realizados sus ensueños de brujas y trasgos, al mirar algunos tritones-hembras, que con un calzón corto de hule y las trenzas al agua, aparecen y desaparecen alternativamente entre las olas, y sirven para vigilar a las Náyades aprendizas (9-V, 151).

Pensando sin duda en sus lectores españoles, Mesonero resuelve el problema moral trasladándolo a un significado estético, y levemente satírico para esas tritones-hembras, aunque, de paso, nos ha informado de que en Francia a la altura de 1840 las mujeres se bañaban en calzón corto y sin ser segregadas de los hombres ${ }^{25}$.

Es en París donde Mesonero vive una experiencia decisiva, que verdaderamente conmovió su visión tradicional de la mujer, y le condujo una vez más a una honrada reflexión. Sucedió mientras recorría deslumbrado los elegantes comercios parisinos, donde descubre: "una falange de seductoras sirenas (estilo antiguo), o ya sea hasta una docena de mujeres fatales (estilo moderno) ricamente ataviadas, como para una soirée, bellamente prendidas, y contando además con una buena porción de gracias juveniles, de amabilidad y destreza mercantil" (13-VI, 190).

El espectáculo de estas dependientas expuestas al público, que unian a la belleza la competencia en su trabajo, le hizo detenerse y anunciar al lector un paréntesis reflexivo:

Esta utilidad, o llámese explotación del trabajo mujeril, es uno de los extremos en que las costumbres francesas se apartan notablemente de las nuestras. [...] nuestras mujeres son más dichosas, si dicha puede llamarse el estar reducidas a una condición pasiva, aunque rodeada de una cierta aureola de adoración. Mas, mirado por otro lado, no deja de tener grandes inconvenientes nuestro sistema; inconvenientes que redundan en perjuicio de la sociedad, y que la misma mujer es la primera a sentir (13-VI, 190-91).

Divaga sobre los pros y los contras, ve triunfar las ventajas, añade ejemplos, y acaba defendiendo una postura que, asombrosamente, coincide con las primeras propuestas feministas de comienzos del siglo $X^{26}$ :

El interés de la mujer está también en recibir un género de educación que la predispone al trabajo, que dobla su valor, y que la emancipa, si ella quiere, de la tiranía del hombre, y de las fuertes cadenas de la seducción. $Y$ no se asusten nuestras damas meridionales con estas ideas, que son las que rigen en todo el norte de Europa y América. El trabajo, la ocupación, es la más agradable compañía; la instrucción la más sólida dote, y la importancia social que reciben con ambas, en nada perjudica al entusiasmo que sus gracias personales pueden inspirar (13-VI, 191).

Como vemos, Mesonero no rehuyó este problema con la recurrente ironía satírica sobre las mujeres que rompian moldes, sino que lo abordó con plena conciencia y re- 
flexionó con afán de objetividad, olvidando los prejuicios. Probablemente resulten asombrosas estas palabras de Mesonero para quienes tuvieran de él una imagen más tradicional, tanto sus lectores de antes como los de ahora, pero creo que ayudan a iluminar y completar su figura, a descubrir en el autor una gran modernidad y una mayor altura intelectual y moral.

\section{LA FASCINACIÓN POR LA TÉCNICA. UNA MIRADA ANTIRROMÁNTICA}

Como sabemos, en más de una ocasión, Mesonero había tomado postura frente al Romanticismo ${ }^{27}$, del que era rigurosamente contemporáneo. Su visión del mundo, según venimos viendo, y sus preferencias estéticas distaban casi punto por punto de las propuestas románticas.

En el discurrir de su viaje nos va dejando a menudo algunas muestras de ese rechazo, unas veces con una alusión irónica: "enmudecería la misma rica y delicada lira de Zorrilla, o el pincel fecundo y grato de Villamil" $(2-\mathrm{V}, 141)$. Más irónica aún, por ejemplo, al describir la fachada de Notre Dame: "en aquella sinfonía de piedra (como le place caracterizarla al entusiasta Víctor Hugo)" (27-VI, 206).

Pero mucho más importante es la razonada exhibición de antirromanticismo que despliega a propósito de algo en apariencia tan ajeno como el trazado urbano. Compara el autor el laberinto de calles estrechas y tortuosas, herencia de la ciudad medieval, con los barrios modernos, de avenidas amplias y luminosas, derechas, enlosadas, que facilitan la comunicación, que "ostentan hoy una comodidad, un lujo, un halagüeño aspecto". De ese contraste surge la reacción de Mesonero, rechazando el pasado medieval, justamente la "época tan encomiada en nuestros días por los poetas y novelistas; de aquella edad media, en que la humanidad se dividía en siervos y tiranos". A esos poetas y novelistas aún alude como: "hombres excéntricos que gustan de trasladarse con su imaginación y con su pluma a las épocas nebulosas" (6-VI, 182).

Frente a esas posiciones de un romanticismo que mira al pasado, Mesonero opone lo que podríamos juzgar como el ideario racionalista de un ilustrado, y todo ello expresado con una intensidad poco frecuente en él: "La civilización, emancipando a la humanidad de tan vergonzoso yugo; elevando la inteligencia a un alto grado de esplendor; revelando al hombre su dignidad, y dándole a conocer los goces que la vida podría ofrecerle, vino a variar el aspecto material de los pueblos; y las ciudades modernas borraron sucesivamente las ominosas trazas de su antiguo barbarismo" (6-VI, 182).

Refuerza aún más sus argumentos con la defensa de unas formas estéticas clásicas, o mejor, neoclásicas, que enfrenta al arte gótico y, simbólicamente, a las ojivas, preferidas por los románticos: "Y digan lo que quieran Víctor Hugo y su comparsa de imitadores, esto vale más que las tortuosas avenidas de la Cour des miracles (hoy convertida en una bonita plaza), y que las puertas ojivas, hora sustituidas por dóricas columnas, por elegantes balaustradas, por amplios y cómodos peristilos" (6-VI, 182).

Por no extendernos más, digamos que en la coherencia de su ideario manifiesta las mismas preferencias respecto al teatro, defendiendo la grandeza de Corneille, de Racine o de Molière frente a los dramones románticos, salvo alguna excepción relativa a Dumas o Víctor Hugo (Antony, Hernani).

Recordemos que, muy al principio, Mesonero anunció su interés por la "vida animada de los pueblos". Ha sido prolijo al describir y explicar las ventajas que ha traído el progreso a la vida humana, en cambio, los célebres monumentos o las obras de arte los ha resuelto con breves trazos, considerando todo ello de sobra conocido. Son urbanismo, viviendas, edificios y servicios públicos, espectáculos, sistemas de comunicación, calidad de vida, los que han causado su admiración, que vive una verdadera eclosión en los seis capítulos dedicados a París, algo imposible de resumir pero fácil de reflejar con la descripción de la actividad comercial:

Paris [...] es el más grande almacén de la moda, la fábrica principal del lujo europeo, y en sus innumerables tiendas vienen a reunirse diariamente todos los adelantos, todos los caprichos de las artes bellas y mecánicas; de suerte que por muy exigente que quiera ser la imaginación del espectador, todavía puede estar seguro de verla sobrepujada por la realidad.

Para proporcionar paso entre dos calles principales, para dar más extensión al comercio y más elegancia a la ostentación 
de la industria mercantil, se establecieron las bellísimas galerías cerradas de cristal (pasagges) de que ya cuenta París más de doscientas, y al paso que de riquísimos bazares de comercio, sirven de grato recurso contra la intemperie y el bullicio de las calles.

Esta actividad de la industria, este poderoso estímulo del interés, ha dado también ocasión a otra especialidad propia de Paris, que consiste en el arte, o más bien la coquetería con que todos aquellos objetos están expuestos al público (13-VI, 189-90).

De igual modo, ya en Bélgica, recibe parecidas impresiones ante su desarrollo industrial:

Lo que más admira en ésta es el movimiento importantísimo de su industria, el gusto y perfección de sus manufacturas, que participan de la solidez inglesa, del gusto francés y de la baratura alemana, sobresaliendo en varios ramos en competencia con las de aquellos países, como, por ejemplo, en todas las obras de hierro, en la fabricación de los carruajes, la del papel, la de las telas de hilo, la de los encajes, y de otros mil objetos [...]. El comercio de libros, sobre todo, [...] es sabido el enorme producto de las imprentas belgas destinadas a reproducir en formas más cómodas e infinitamente más baratas todas las obras francesas (25-VII, 239) ${ }^{28}$.

La admiración de Mesonero se convierte en entusiasmo ante las conquistas de la técnica. Así, saliendo de Burdeos nos descubre: "Uno de los más bellos monumentos de la Francia moderna es el soberbio puente de Cubrac, obra de estos últimos años, y de cuya prodigiosa extensión y admirable artificio siento no tener los datos suficientes para estamparlos aquí" 29 . En efecto, siempre que están a su alcance nos ofrece datos exhaustivos, fruto del estudio documentado.

La cima de esta fascinación por los adelantos tecnológicos la alcanza el autor al recorrer y estudiar la red de ferrocarriles construida en Bélgica en muy pocos años. Como es natural, la denomina traduciendo el término francés, "caminos de hierro", con el que da título a todo un artículo (XIII); tal "objeto", aún no existía en España ${ }^{30}$.

Mesonero había viajado ya en los "caminos de hierro" de Inglaterra y de Francia durante su primer viaje de 1833, pero solo se habian construido en ambos países algunas líneas cortas $^{31}$. Bélgica era el primer país que había planificado y construido toda una red de vías, capaz de comunicar, ya en 1840, diez de sus ciudades más importantes, y facilitaba la comunicación con Francia y Alemania. Mesonero comprendía que se trataba del "invento característico del siglo en que vivimos". Lo estudió exhaustivamente, desde el decreto del gobierno que impulsó el proyecto, que considera obra "de verdadero patriotismo", siguiendo con su construcción, los plazos de tiempo, su extensión, el capital invertido, las partidas para obras, materiales, máquinas, vehículos; nada escapó a la lupa de Mesonero. Y aún prosiguió con el funcionamiento de las líneas, el número creciente de viajeros, los precios, los beneficios, las dotaciones de vehículos, los horarios, el confort de los coches (o los "waggons"), el trabajo de los operarios; todo acrecentaba su admiración por el perfecto funcionamiento: "confieso que me ha entusiasmado y sobrepujado a mis esperanzas [el espectáculo] que ofrece un pueblo donde esta clase de comunicación se halla establecida por sistema general, y las variaciones fundamentales que produce en su vida social, política y mercantil" (1-VIII, 248).

El interés, la grandeza del invento residía precisamente en lo que significaba para el progreso de la sociedad. Con esta idea había comenzado su artículo, citando las palabras de Michel Chevalier ${ }^{32}$ : "si el transporte de las mercancías crea la riqueza, el de los hombres produce nada menos que la civilización" (1-VIII, 245).

El pormenorizado artículo adquiría así un significado de gran trascendencia. Pero Mesonero añadió aún otro nuevo, de signo estético, que nos causa una gran sorpresa. Volvió a ridiculizar a los "señores poetas" románticos, que se sentían en un siglo carente de poesía, invitándoles a contemplar junto a él la actividad de la estación de Malinas:

verían, repito, el más variado cuadro que la civilización moderna puede ostentar, mirando llegar por todas partes, partir en todas direcciones continuamente máquinas gigantescas, despidiendo el resplandor vivísimo del fuego que las alimenta, dejando en pos de sí una faja negra y espesa de humo que marea su camino, despidiendo un mugido bronco y monótono, y avanzando o alejándose con mágica celeridad. Verían en pos de ellas una fila interminable de carruajes que, no bien hecho alto, vomitan de su seno una población entera, miles de gentes de todas edades, sexos y condiciones [...].

Sorprendido el viajero con la grata variedad de tan animado espectáculo, saboreando en su imaginación la facultad voladora que la industria moderna pone a sus pies [...]. En 
el mismo día puede si gusta dormir en Holanda; o almorzar en Prusia, comer en Bélgica, y cenar en Francia o Inglaterra; y todo sin la más mínima molestia, casi sin apercibirse de haber variado de sitio. Dígase después si es o no poética esta situación (1-VIII, 247).

En efecto, esta es la sorpresa, para asombro de los lectores actuales, Mesonero da un enorme salto de varias generaciones y anticipa un sentido estético que ha de llegar en 1910 con el Manifiesto futurista de Marinetti ${ }^{33}$. En ninguno de los otros artículos, despliega Mesonero tal entusiasmo por las diversas obras de arte que conoce de antemano. Lo que ha deslumbrado su mirada ha sido la imagen anticipada de un mundo futuro que sabe ver llegar.

\section{Política, Religión e historia en la mirada}

Se ha venido dibujando hasta aquí el complejo universo personal de Mesonero, que deshace la simplista imagen de un madrileño entusiasta observador del microcosmos de su ciudad. Por el contrario, a lo largo de este viaje su mirada ha transparentado una conciencia lúcida, atenta a las realidades más diversas, culta, refinada y tolerante.

Nunca emite juicios políticos, ni adopta una postura ideológica definida; es la propia realidad observada la que genera breves alusiones que perfilan en parte cuál es su ideal. Recordemos que juzga como obra de "verdadero patriotismo" el proyecto de construcción de los "caminos de hierro" por parte del gobierno belga, al que más adelante define como "gobierno justo, liberal y tolerante", y al país, como "centro convergente de todos los más civilizados de Europa" (25-VII, 237). Siempre roza Mesonero los conceptos políticos como de pasada; al revisar las normas urbanísticas de las calles de París, las resume en lo que "el interés general tiene derecho a impedir al interés privado" (6-VI, 184), una idea, evidentemente, de fondo democrático.

No hay alusiones a la política española, o solo en la idea que va dejando en el lector de un país mal administrado. En cambio, del pasado histórico no rehuye hacer duras alusiones; así, evocando la dominación española en Flandes, habla de: "la odiosa memoria que de esta ha quedado en aquellos países, a causa de la intolerancia y crueldad de los gobiernos de los Felipes" (25-VII, 238). Y también, mientras viaja, siente: "ocupada la memoria en el recuerdo de las páginas de nuestra historia nacional escritas con sangre en aquellas hoy felices campiñas" (8-VIII, 254). En aparente contradicción, tal vez por temor a generar dudas sobre su patriotismo, se declara: "un español, apasionado ardiente de nuestras antiguas glorias" (22-VIII, 270).

En la descripción de la vida idílica de la campiña belga está contenido de forma aproximada el ideario político y social de nuestro autor, una imagen del "bien estar":

\begin{abstract}
Pueblos pintorescos y variados, campos bellísimos, bosques deliciosos y bien cultivados, castillos y quintas de trecho en trecho, donde habitan la mayor parte del año sus opulentos dueños vecinos de la corte o de otras ciudades; la más completa seguridad a todas horas; la frecuencia de comunicaciones; animación en los trabajos del campo y de la industria durante toda la semana; fiestas religiosas en las modestas iglesias; bailes y juegos en las plazas los domingos; autoridad paternal en los poderosos; docilidad y cariño en los subalternos; uniformidad del existir, moderación en los deseos; respeto a la propiedad, y amor a la familia y al pais (15-VIII, 262-63).
\end{abstract}

Todo ello alcanzado, recordemos, por un gobierno "justo y liberal" que actuaba con "verdadero patriotismo". Por todas estas alusiones, Mesonero se define como un espíritu liberal moderado, que defiende el progreso social, aunque se mantiene muy distante de los procesos revolucionarios y de la lucha de clases que se extendian por Europa en aquellos mismos tiempos.

En cuanto a la religiosidad de Mesonero, son pocas las ocasiones en que se refleja, pero lo hace de forma nítida como un ferviente católico. Evocando las catedrales españolas, recuerda no solo su gran valor artístico, sino que son "dignos altares del Altísimo, por su religioso recogimiento" (30$V$, 175). En París, visitando el Panteón Nacional, lamenta: "un inmenso vacío producido por la falta de culto, por la ausencia de la Divinidad, desterrada inoportunamente de aquel sitio para dar lugar al apoteosis de las miserables grandezas humanas" (27-VI, 206). Al mismo tiempo celebra la recuperación del culto en las iglesias, producida en los siete años transcurridos desde su primer viaje: "Entonces hallé desiertas casi del todo las iglesias de la capital y perdida la voz de sus oradores en el silencio de sus bóve- 
das; ahora con dificultad he podido penetrar en San Roque durante la misa del domingo, y he escuchado al reverendo Padre Lacordaire, vestido con el hábito de Santo Domingo, predicar en la iglesia de Nuestra Señora delante de una sociedad numerosa y escogida" (27-VI, 207).

Es en Bélgica donde manifiesta con más satisfacción su religiosidad: "se observa el esmero en el culto religioso, y la concurrencia del pueblo a los divinos oficios: en este punto la mayoría del pueblo belga, que profesa la religión católica, lleva mucha ventaja al pueblo francés" (25-VII, 238). En Brujas, su satisfacción se eleva a una intensa vivencia y a una evocación: "cuando entraba en sus templos y me hallaba con aquella media luz, producida por las pintadas cristalerías, con el pálido resplandor de cien lámparas delante de los altares; con las imágenes de la Virgen adornadas con ricas vestiduras; con el olor a incienso, y los ecos del órgano religioso, parecíame por un momento hallarme trasportado a nuestra España" (8-VIII, 253).

\section{La historia reciente: Moratín y Napoleón}

Dos experiencias vividas por Mesonero en París merecen atención especial, ambas vinculadas a la historia reciente de España y Francia, y envueltas en un evidente significado político. Sucedió la primera mientras el autor visitaba el cementerio del Père-Lachaise, donde se encontró con las tumbas de españoles ilustres que habian emigrado huyendo de la persecución fernandina ${ }^{34}$.

Mesonero se sintió profundamente conmovido y agradecido a un país que había honrado la memoria de sus compatriotas "muertos en el destierro"; pero su conmoción fue mayor cuando se vio delante de la tumba de Moratín, que, para mayor gloria, estaba situada junto a las de Molière y Lafontaine. Yacía en el mausoleo de la familia Silvela que lo había protegido en sus últimos años ${ }^{35}$.

Mesonero no incluyó este descubrimiento en los artículos publicados en el Semanario Pintoresco dedicados al viaje. El Père-Lachaise ocupaba un breve párrafo en el artículo IX, del 4 de julio de 1841. En cambio, casi un mes después del final de la serie, publicó un artículo aislado que tituló "El sepulcro de Moratín en el cementerio de París" (26 de septiembre), donde elevando el tono de sus palabras de modo inesperado, vertió un doloroso alegato sobre el destino que España había dado a sus grandes hombres:

Las convulsiones políticas que desde los primeros años del siglo actual agitan a España, han venido a ser aun más fatales a las letras y a los que las cultivan, que la indiferencia o el fanatismo de los siglos precedentes [...].

Han desaparecido en este desgraciado período los Islas, los Jovellanos, los Cienfuegos, los Meléndez, los Moratines [...] dignos del respeto y del entusiasmo nacional por su grande ingenio y laboriosidad. Y sin embargo, han muerto envueltos en la desgracia, vilipendiados y proscriptos, pobres y ancianos los más de ellos, y lejos de una patria a quien habian ilustrado con su saber. [...] El siglo XIX, apellidado "de las luces", llevando más allá su intolerancia política, ha visto inclinar su venerable cabeza en tierra estraña [sic] a Meléndez y Moratín (p. 305) ${ }^{36}$.

Con sus palabras, Mesonero se comprometía con los perseguidos y se pronunciaba a favor de la tolerancia, y parece evidente que esas palabras podían parecer excesivas a importantes sectores de la sociedad, más próximos a la posición que él denunciaba. Asi se explica que el artículo fuera segregado del resto. Más aún, que el largo alegato fuera suprimido y el texto recortado para insertarlo en la edición del libro que el autor publicó en el mismo año; y así apareció en las otras ediciones de veinte y cuarenta años después.

La otra gran experiencia vivida por nuestro autor pertenecia a la historia de Francia. Presenció en París la solemne ceremonia de la llegada de las cenizas de Napoleón, procedentes de Santa Elena, para depositarlas en los Inválidos. Aludió al magno acontecimiento cerrando ya el último artículo dedicado a París. Sorprendentemente, se disculpaba por no describirlo, a pesar de la gran importancia que le atribuía: "la satisfacción de haber asistido el 15 de diciembre de 1840 al más grandioso espectáculo de este género que acaso haya ofrecido u ofrezca en adelante el siglo actual" ${ }^{37}$. Es decir, renunciaba a trasladar a sus lectores el que consideraba acontecimiento del siglo, algo muy difícil de entender.

Es necesario dejar pasar muchos años para resolver este enigma. En las citadas ediciones posteriores de 1862 y 1881, incluye el despliegue de aquel espectáculo bajo el título "Las exequias del emperador", uniéndolo al artículo original en el punto en que lo interrumpió. Lo describía con 
sumo detalle, algo muy difícil de reconstruir transcurridos tantos años. Se deduce por ello que el texto fue escrito junto a los otros, al regreso del viaje, pero el autor lo mantuvo inédito; y nuevamente parecen ser la causa las circunstancias políticas de España, que mantendrian aún viva la herida de la guerra contra el invasor. Mesonero, prudentemente, evitó herir sensibilidades describiendo el acto en que era glorificado.

\section{Una imagen renovada de Mesonero Romanos}

Mesonero manifestó siempre un gran aprecio por esta parte de su obra, como reflejan pasado el tiempo las palabras aludidas de su editor en 1862, que él mismo reitera con leve modificación y vierte en la edición de 1881, invitando a apreciar "en lo que valen el exquisito tacto, el buen criterio del escritor filósofo y patriota, que haciendo abstracción del orgullo patrio y de arrogancia inoportuna, se atrevió a reconocer y señalar hace cuarenta años aquel notable desnivel de nuestra cultura y progreso material, promoviendo atrevidamente su remedio"38. En tan concisas palabras resumía Mesonero al final de su vida el gran significado que atribuía a aquellos artículos de su juventud en los que vertió su más honda forma de mirar la realidad.

Recordemos que, como en superposición de imágenes, lo que el autor ve le hace evocar lo que sabe de su país y se esfuerza en combinar ambas imágenes de modo crítico, reflexionando sobre los contrastes, y aunque evita emitir juicios rotundos, es en esos contrastes donde nace la visión crítica de España, profunda aunque vertida con cautelosas palabras. El universo ideológico de Mesonero se enfrenta así a realidades nuevas que lo cuestionan, y su mérito está en no eludir ese conflicto, en intentar comprender, justificar y aceptar muchas veces, en todo caso, adoptar una actitud tolerante, palabra que se reitera en su discurso. Sobre la mirada objetiva que iba creando el reportaje del viaje, el autor filtraba una mirada dolorida, aunque no sentimental, muy lúcida, extendida sobre las realidades descubiertas, generando un debate íntimo entre la crítica y el amor a su país; una mirada de calidad moral.

A través de todos los textos aludidos que fueron fruto de su actividad viajera, la figura de Mesonero se ofrece renovada y enriquecida a nuestros ojos, y se asemeja a la de un discípulo de Jovellanos en muchos aspectos, o a la de su amigo Larra en otros. La herencia ilustrada que refleja Mesonero se halla muy evolucionada como corresponde a un autor situado ya cerca de la mitad del siglo XIX, un hombre que es testigo del progreso técnico que en pocas décadas ha alcanzado la humanidad. Y Mesonero no solo es testigo, sino entusiasta admirador de ese proceso.

Cumplió su proyecto sirviéndose de un lenguaje sobrio, exacto, cuidadosamente despojado de retoricismo. Del mismo modo que atraía su interés "la vida animada de los pueblos", se interesaba por el lenguaje más vivo; por ello se acumulan en los artículos las expresiones tomadas del francés, o del inglés en menor medida, para poder aludir a realidades inexistentes todavía en España, realidades y palabras que se proyectaban hacia el futuro, que lo anunciaban; recordemos tantos ejemplos ${ }^{39}$.

Para comprender mejor la trascendencia de su labor, no olvidemos que, a través de esta mirada de Mesonero, los lectores del Semanario Pintoresco Español contemplaron las modernas sociedades europeas; y aún se acrecienta su repercusión al recordar los miles de suscriptores a los que llegaba la revista en España, e incluso en América.

Y podriamos recordar, para terminar, las palabras de Larra, quien supo ver en el colega y amigo muchos de los valores que hemos subrayado en estas páginas que él no llegó a conocer. Lo consideraba: "uno de nuestros pocos prosistas modernos: culto, decoroso, elegante, florido a veces, y casi siempre fluido en su estilo, castizo y puro en su lenguaje, y muy a menudo picante y jovial". Pero no solo veía sus valores estéticos, también supo ver Larra el valor humano y social que encerraban los artículos de costumbres de su compañero El Curioso Parlante: "Uno de los medios esenciales para encaminar al hombre moral a su perfección progresiva, consiste en enseñarle a que se vea tal cual es. El autor del Panorama ha puesto ante los ojos de nuestra sociedad un espejo donde puede tocarse, y hacer desaparecer los lunares que la bondad de la luna debe presentar a su vista ${ }^{40 "}$.

Aún se habrian ensanchado estas generosas palabras que firmó Fígaro, si hubiera vivido para conocer el gran testimonio que nos legó Mesonero en estas sus Impresiones de viaje, y habría descubierto el fondo cosmopolita de su mirada, que mantuvo abierta de par en par para poder contemplar la Europa de su tiempo. 
1 "Recuerdos de viaje. Introducción", Semanario Pintoresco Español, 25-IV, 1941, p. 134. En las notas, se aludirá al Semanario con las iniciales SPE.

2 Escobar, José y Álvarez Barrientos, Joaquín [edic.] (1994): Memorias de un setentón, Tomo II, cap. XIV (III), Editorial Castalia y Comunidad de Madrid, Madrid, pp. 508-510.

3 lbid.

4 Enrique Rubio Cremades (Mesonero Romanos: impresiones y recuerdos de su primer viaje por Europa [18331834], Biblioteca Cervantes Virtual) ha rastreado todos estos testimonios en diferentes etapas de la obra de Mesonero, incluso en la obra publicada póstumamente por los hijos del autor como Trabajos no coleccionados (Madrid, Imprenta de los hijos de M. G. Hernández, 1905, T. II) en la que se incluye el apartado "Fragmentos de un diario de viaje" (pp. 586$608)$. En dicho texto, se incluye a su vez como extensa nota 1 el guión de las anotaciones de viaje, que Mesonero no llegó nunca a desarrollar. pero que resulta de gran utilidad para conocer el itinerario recorrido y aquellos aspectos que en cada lugar atrajeron especialmente su atención.

5 Recuerdos de viaje por Francia y Bélgica, en 1940 a 1841 [1881] (El Curioso Parlante), edición corregida y aumentada, volumen IV, Oficinas de la Ilustración Española y Americana (Imprenta de sucesores de Rivadeneyra), Madrid, MDCCCLXXXI, p. 277, nota 1. Esta edición es idéntica a otra de 1862 (Establecimiento Tipográfico de Francisco de Paula Mellado, Madrid), con leves cambios en las notas y en la "Advertencia del editor". En ambas ediciones modificó levemente el título del artículo: "De vuelta a casa (Epílogo)".

6 En edición citada de 1881, p. 157, nota 1. El artículo ocupa las páginas 157-164.

7 Boletín de La Revista Española [Periódico] (1834), Año IV, N. 226, miércoles 28 de mayo.

8 Lo incluyó como capítulo VIII en las ediciones de 1862 y 1881.

9 Madrid, Imprenta de Don Tomás Roldán, 1. de enero de 1835. "Rápida ojeada..." ocupa, dentro del "Apéndice...", la mayor extensión: pp. 31 133.

10 Ibid., p. 34

11 Después de fundarlo en 1836, lo dirigió hasta 1842.

12 Alude a la primera guerra carlista.

13 "El sepulcro de Moratín en el cementerio de Paris", p. 305-7.

14 Recuerdos de viaje por Francia y Bélgica en 1840 y 1841 (1841) su autor El Curioso Parlante, Madrid, Imprenta de D. Miguel de Burgos.

15 Editada en Establecimiento Tipográfico de Francisco de Paula Mellado, Madrid, 1862 (ver nota 5).

16 Perteneciente al primer viaje del autor (1833-1834); ver nota 7.

17 La publicó en verso en el SPE (20 de junio de 1841), al margen de la serie de los artículos del viaje.

18 Apareció en Oficinas de la llustración Española y Americana (Imprenta de sucesores de Rivadeneyra), edición corregida y aumentada, Madrid, MDCCCLXXXI, volumen IV (ver nota 5).

19 Ibid., 1881, p. VI.

20 SPE, 9-V-1841, p. 142.

21 SPE, 25-IV-1841, p. 136. Para evitar la acumulación de notas, al final de las citas tomadas del SPE se consignarán entre paréntesis la fecha (solo día y mes, si son referidos a 1841) y la página.
Aceptado: 5 de julio de 2012 
22 Objetos serán edificios, costumbres, transportes, cosas, etc., aquello de lo que va a tratar.

23 La palabra no existe en castellano aún y Mesonero la adapta con plural francés. Como es lógico, son innumerables los ejemplos de galicismos, en general, nombrando realidades inexistentes aún en España.

24 Tres cuartos de siglo después, la escritora Carmen de Burgos manifestaba la misma inquietud en sus frecuentes recorridos por Europa; visitando la Costa Azul medita: "se aprovecha la bondad del clima para hacer la estancia agradable y conservar una hermosa estación de invierno. Nosotros tenemos una hermosa 'costa azul' que se extiende desde Valencia a Almeria; pero carece del 'confort' que aqui encuentran los extranjeros" (Por Europa (1906), Barcelona, Ed. Maucci, p. 147).

25 Para subrayar la distancia con España, recordemos que, todavía a comienzos del siglo $\mathrm{XX}$, las mujeres pintadas por Sorolla, incluso las niñas, se bañaban en las playas con largos camisones.

26 Carmen de Burgos, la gran pionera del feminismo en España, desde 1901 reclamaba en la prensa exactamente lo mismo: educación, trabajo, emancipación, sin renunciar a los atributos de la mujer.

27 Es muy célebre al respecto su artículo "El Romanticismo y los románticos", SPE, 10 de septiembre de 1837. Pero, según indicamos más arriba, es anterior "Entierro de Victor Ducange" (ver nota 7).

28 Recordemos que la importación por parte de Mesonero de este tipo de maquinaria en su anterior viaje, permitió el éxito y difusión del Semanario Pintoresco Español por su bajo precio.
29 La referencia no aparece en la edición del Semanario sino en las ediciones en libro, desde la primera de 1841, al comienzo del capítulo II.

30 La primera línea de ferrocarril se inauguró en España en 1848 (Barcelona-Mataró).

31 La primera línea para pasajeros en Inglaterra, Manchester-Liverpool, funcionó desde1830, así como la Londres-Birmingham. En Francia, desde 1831, Lyon-Saint-Étienne (58 km). Desde 1837 funcionó ParísSaint Germain (18 km).

32 Michel Chevalier (1806-1879), politico y economista francés, sansimoniano y luego liberal. Entre sus obras primeras, Des Intérêts matériels en France, 1837.

33 Recordemos su defensa de una nueva estética, la de la técnica, de la energía, de la velocidad, y sus eslóganes, en los que una veloz locomotora supera en belleza a una imagen clásica como la Venus de Milo.

34 Se concentraban en un espacio conocido como "la isla de los españoles".

35 En las ediciones citadas de 1862 y de 1881, Mesonero recuerda que tiempo después, el 12 de octubre de 1853, las cenizas de Moratín fueron trasladadas a Madrid (1881, p. 154).

36 Recordemos que, según el autor, durante su primer viaje de 1833, camino de París, había visitado la tumba de Meléndez Valdés en Montpellier (ver nota 4).

37 Semanario Pintoresco Español, 18 de julio de 1841, p. 231.

38 Edición citada, 1881 (ver nota 5), p. VI.

39 Los aspectos léxicos y estilísticos del lenguaje utilizado por Mesonero merecen una especial atención, pero exceden los límites de espacio en este estudio.
40 Larra, M. J. de: "Juicio crítico del Panorama Matritense", por Fígaro, El Español, junio 20 de 1836. Tomado de R. de Mesonero, Escenas Matritenses (1987) Madrid, Clásicos Universales Planeta, Barcelona, p. 364. Edición de M. a del Pilar Palomo.

\section{BIBLIOGRAFÍA}

Burgos, Carmen de (1906): Por Europa, Barcelona, Ed. Maucci.

Larra, Mariano J. de (1836): "Juicio crítico del Panorama Matritense", por Figaro, en El Español, 20 de junio, Madrid, Imprenta de El Español.

Mesonero Romanos, R. (1834): Boletín de La Revista Española (Periódico), Año $\mathrm{IV}$, n. ${ }^{\circ} 226$, miércoles 28 de mayo. Madrid, Imprenta de I. Sancha.

Mesonero Romanos, R. (1835): "Apéndice al Manual de Madrid (Descripción de la corte y de la villa)" 1 de enero, Madrid, Imprenta de D. Tomás Roldán.

Mesonero Romanos, R. (1841): "Recuerdos de viaje. Introducción", Semanario Pintoresco Español, 25-IV, Madrid, Imprenta de Tomás Jordán.

Mesonero Romanos, R. (1841): Recuerdos de viaje por Francia y Bélgica en 1840 y 1841, su autor El Curioso Parlante, Madrid, Imprenta de D. Miguel de Burgos.

Mesonero Romanos, R. (1862): Recuerdos de viaje por Francia y Bélgica en 1840 y 1841, su autor El Curioso Parlante, Madrid, Establecimiento Tipográfico de Francisco de Paula Mellado.

Mesonero Romanos, R. (1862): Recuerdos de viaje por Francia y Bélgica en 1840 y 1841, su autor El Curioso Parlante, Oficinas de la llustración Española y Americana, edición corregida y aumentada, volumen IV, Madrid, Imprenta de sucesores de Rivadeneyra. 
Mesonero Romanos, R. (1905): "Fragmentos de un diario de viaje", apartado de Trabajos no coleccionados, Madrid, Imprenta de los hijos de M. G. Hernández, T. II, pp. 586-608.

Mesonero Romanos, R. (1994): Memorias de un setentón, Tomo II, cap. XIV (III), edición de José Escobar y Joaquín Ál- varez Barrientos, Madrid, Castalia y Comunidad de Madrid.

Palomo, M. ${ }^{a}$ del Pilar (1987): Edición de Escenas Matritenses, Barcelona, Clásicos Universales Planeta.

Rubio Cremades, Enrique (2005): "Mesonero Romanos: impresiones y recuerdos de su primer viaje por Europa (1833-
1834)", en Fundación Biblioteca Virtual Miguel de Cervantes. Portal: Biblioteca de Ramón de Mesonero Romanos. CDU: 821.134.2 Mesonero Romanos. 07. 